\title{
INVESTMENT THROUGH PUBLIC PRIVATE PARTNERSHIP (PPP): THE IMPACT OF PPP ACTIVITIES ON THE GROWTH OF GDP
}

\author{
DOI: 10.17261/Pressacademia.2020.1257 \\ PAP- V.11-2020(29)-p.150-152
}

Hakan Yurdakul ${ }^{1}$, Rifat Kamasak ${ }^{2}$

${ }^{1}$ Presidency of The Republic of Turkey, Ankara, Turkey.

hakan.yurdakul@tccb.gov.tr, ORCID: 0000-0003-3575-1288

${ }^{2}$ Yeditepe University, Istanbul, Turkey.

rifat.kamasak@yeditepe.edu.tr, ORCID: 0000-0001-8768-3569

\section{To cite this document}

Yurdakul, H., Kamasak, R. (2020). Investment through Public Private Partnership (PPP): The impact of PPP activities on the growth of GDP. PressAcademia Procedia (PAP), V.11, p.150-152

Permanent link to this document: http://doi.org/10.17261/Pressacademia.2020.1257

Copyright: Published by PressAcademia and limited licensed re-use rights only.

\section{ABSTRACT}

Purpose- The purpose of this study is to investigate the relationship between Public Private Partnership (PPP) activities and their impact on Gross Domestic Product (GDP).

Methodology- The study employs a time series dataset of Turkey that includes the number of PPP activities and GDP between $1990-2014$. The dataset was analyzed by Vector Auto Regression (VAR) method.

Findings- The analysis reveals that there is only a weak association between GDP and PPP.

Conclusion- The reason of this result might be related with the other macroeconomic factors that affect the growth of GDP as a proxy of overall economic development. Moreover, policy makers should consider other benefits of PPP on the way of making positive contributions to the budget constraints, heavily indebtedness, and lack of sufficient funds of countries.

Keywords: Public Private Partnership, investment, GDP, Vector Auto Regression, Turkey.

JEL Codes: A10, C22, 011

\section{INTRODUCTION}

In recent years, public private partnership (PPP) has become a preferred model to promote the infrastructure-related investments of countries (Maurya \& Srivastava, 2019; Sharma, 2012). The determinants of PPP activities have been searched by several indicators (i.e. inflation, money supply, exchange rates and market capitalization) that were thought to be influential on the decisions to use PPP (Erie, Kogan \& MacKenzie, 2010; Hammami, Ruhashyankiko, \& Yehoue, 2006).

Yet, among these indicators gross domestic product (GDP) was considered as a very impactful determinant for selecting the PPP models. This paper explicates the relationship between GDP and PPP activity by using World Development Indicators (WDI) and The Private Participation in Infrastructure (PPI) Project Databases for the period 1990 to 2014 (The World Bank, 2017).

\section{LITERATURE REVIEW}

Public Private Partnership (PPP) is defined as "a long-term contract between a private party and a government entity, for providing a public asset or service, in which the private party bears significant risk and management responsibility, and remuneration is linked to performance" (World Bank, 2018). According to Hemming (2006), PPP refers to arrangements where the private sector supplies infrastructure assets and infrastructure-based services that traditionally have been provided by the government. PPP Handbook of Asian Development Bank (2007) presents a framework in which PPP "describes a range of possible relationships among public and private entities in the context of infrastructure and other services" (p. 1).

In line, Greve (2003) suggests that PPPs is "just another catchy piece of terminology that governments would like to promote to keep off the attention of the more mundane contracting for public services arrangements" (p. 60). PPPs may play significant roles in contributing the participative firms and the whole economy. While a strong PPP allocates the tasks, obligations, and risks among the public and private partners in an optimal way, effective PPPs recognize that the public and the private sectors each have certain advantages, relative to the other, in performing specific tasks (Altug \& Firat, 2018; Hammami et al., 2006). 
GDP is considered as a significant macroeconomic indicator that gives distinctive clues about the economic growth of a country (Calderon, Moral-Benito, \& Serven, 2011; Canning \& Bennathan, 2000). Macroeconomic theory suggests that an increase in investment in PPPs result to a significant growth in GDP, thus PPP activities are associated positively with GDP growth (Pimentel, Aubyn, \& Ribeiro, 2017).

The idea is that PPP enables countries to complete projects earlier than what would otherwise be then this may result in increasing the growth of GDP. Literature on the impact of PPP on macroeconomic variables is relatively limited compared to the volume of the studies on the impact of public investment. An exception is a study by Pimentel et al. (2017) which estimated the effect of PPP on GDP. The results show that PPP has a positive effect in GDP. This paper analyses the investment in PPP in a macroeconomic perspective through inves tigating the aggregated effects of investment in PPP in another macroeconomic aggregate, GDP.

\section{DATA AND METHODOLOGY}

The World Bank's Private Participation in Infrastructure (PPI) database which comprises the data of Turkey's infrastructure based PPP activities and GDP growth provided by World Development Indicators (WDI) of the World Bank (The World Bank, 2017) for the period 1990 to 2014 were used. Figure 1 shows the number of PPP activities in Turkey. The empirical link between PPP activities and GDP is analyzed by the Vector Auto Regression (VAR) methodology.

Figure 1: Number of PPP Projects per Year for Turkey (1990-2014)

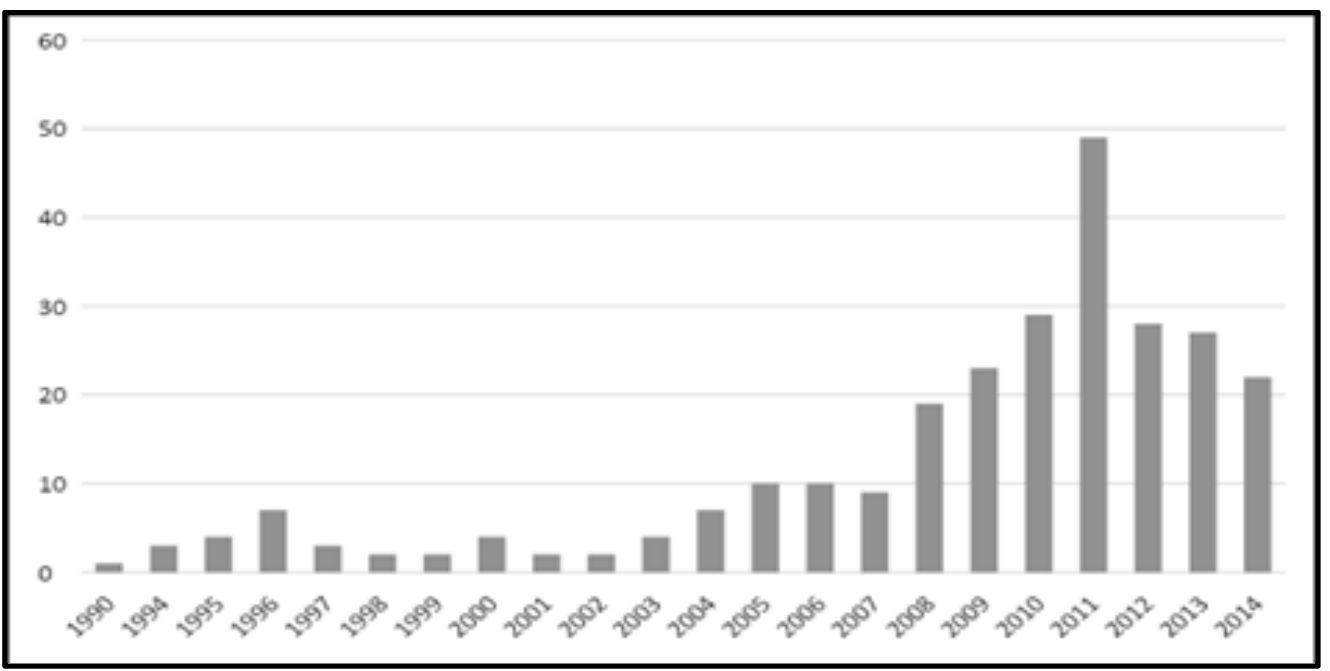

Source: The World Bank Private Participation Infrastructure Database. Retrieved from http://ppi. worldbank.org/data.

\section{FINDINGS}

VAR models are used for understanding the effect of a change in one variable on the other one. PPP and GDP are modelled using lags of those variables. Then, using the system one can assess the impact of an increase in PPP on the growth in the coming period. It is found that for 1 unit of increase in PPP (in this case number of PPP projects), GDP growth rate increases by 0.08 percent at the end of the fifth year (see figure 2).

Figure 2: The Relation between GDP and Number of PPI Projects

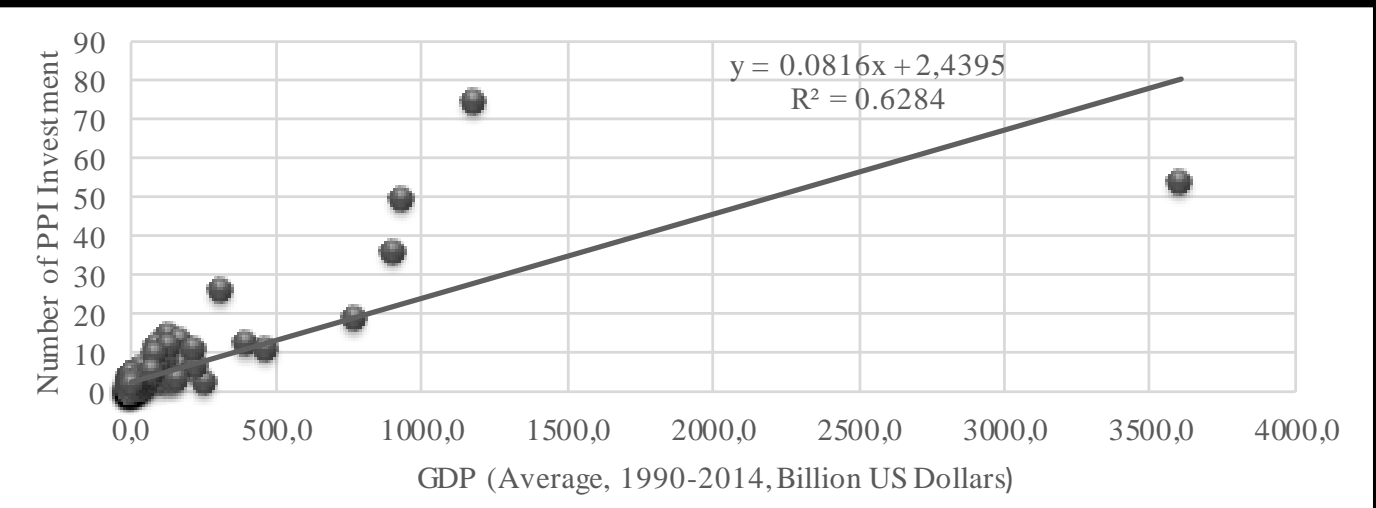




\section{CONCLUSION}

The study finds a weak association between the number of PPP projects and GDP growth in Turkey. The reason of this result mig ht be related with the other macroeconomic factors that affect the growth of GDP as a proxy of overall economic development. Therefore, the use of a single variable to explain the changes in GDP can be considered as a weakness of this paper. One country specific explanation regarding this result might be that PPP projects in the Turkish context have long term payback investment periods, thus the real impact of PPP activities might not be reflected on the findings. A more comprehensive study that includes the outcome of PPP in a longer period is recommended. Moreover, the policy makers who make economic development decisions should not over emphasize the impact of PPP on GDP growth and consider other benefits of PPP on the way of making positive contributions to the budget constraints, heavily indebtedness, and lack of sufficient funds of countries.

\section{REFERENCES}

Altug, S., \& Firat, M. C. (2018). Borrowing constraints and saving in Turkey. Central Bank Review, 18(1), 1-11.

Asian Development Bank (2007). Public-Private Partnership Handbook. https://www.adb.org/sites/default/files/institutionaldocument/31484/public-private-partnership.pdf

Calderon, C., Moral-Benito, E., \& Luis, S. (2011). Is infrastructure capital productive? A dynamic heterogeneous approach. Policy Research working paper; No. WPS 5682; Paper is funded by the Knowledge for Change Program (KCP). Washington, DC: World Bank.

Canning, D., \& Bennathan, E. (2000). The social rate of return on infrastructure investments. World Bank Working Paper, WPS2390, World Bank, Washington DC.

Erie, S. P., Kogan, V., \& MacKenzie, S. A. (2010). Redevelopment, San Diego Style: The limits of Public-Private Partnerships. Urban Affairs Review, 45(5), 644-678.

Greve, C. (2003). Public-private partnerships in Scandinavia. International Public Management Review, 4(2), 59-69.

Hammami, M., Ruhashyankiko, J-F., \& Yehoue, E. B. (2006). Determinants of Public Private Partnership in infrastructure. IMF Working Paper, WP/06/99, 1-37.

Hemming R. (2006). Public-Private Partnerships, Realizing the Potential for Profitable Investment in Africa, High-Level Seminar Organized by the IMF Institute and the Joint Africa Institute, Tunisia. https://www.imf.org/external/np/seminars/eng/2006/rppia/pdf/hemmin. pdf.

Maurya, D., \& Srivastava, A. K. (2019). Managing partner opportunism in public-private partnerships: The dynamics of governance adaptation. Public Management Review, 21(10), 1420-1442.

Pimentel, I., Aubyn, M., \& Ribeiro, N. (2017). The impact of investment in Public Private Partnerships on Public, Private investment and GDP in Portugal, Working Papers Department of Economics 2017/13, ISEG - Lisbon School of Economics and Management, Department of Economics, Universidade de Lisboa.

Sharma, C. (2012). Determinants of PPP in infrastructure in developing economies. Transforming Government: People, Process and Policy, 6(2), 149-166.

The World Bank (2017). The Private Participation in Infrastructure (PPI) Project Database, Washington, DC. https://ppi. worldbank.org/en/ppidata

The World Bank (2017). World Development Indicators (WDI) Database, Washington, DC. https://databank.worldbank.org/source/worlddevelopment-indicators

The World Bank (2018). What are Public Private Partnerships? https://ppp.worldbank.org/public-private-partnership/overview/what-arepublic-private-partnerships 